\title{
A systematic review of interventions for preventing tobacco sales to minors
}

\author{
Lindsay F Stead, Tim Lancaster
}

\begin{abstract}
Objective-To assess the effectiveness of interventions to reduce underage access to tobacco by deterring shopkeepers from making illegal sales.

Method-Systematic literature review.

Data sources-The Cochrane Tobacco Addiction group specialised register and Medline. Studies of interventions to alter retailer behaviour were identified. The terms used for searching combined terms for smoking and tobacco use with terms for minors, children or young people, and retailers, sales or commerce.

Study selection-Studies in which there was an intervention with retailers of tobacco, either through education about, or enforcement of, local ordinances. The outcomes were changes in retailer compliance with legislation (assessed by test purchasing), changes in young people's perceived ease of access to tobacco products, and changes in smoking behaviour. Controlled studies with or without random allocation of retail outlets or communities, and uncontrolled studies with pre- and post intervention assessment, were included.
\end{abstract}

Data extraction-Two reviewers assessed studies for inclusion. One extracted data with checking by the second.

Data synthesis-The results were synthesised qualitatively, with greater weight given to controlled studies. Thirteen of 27 included studies used controls.

Results-Giving retailers information was less effective in reducing illegal sales than active enforcement and/or multicomponent educational strategies. No strategy achieved complete, sustained compliance. In three controlled trials, there was little effect of intervention on youth perceptions of access or prevalence of smoking.

Conclusions-Interventions with retailers can lead to large decreases in the number of outlets selling tobacco to youths. However, few of the communities studied in this review achieved sustained levels of high compliance. This may explain why there is limited evidence for an effect of intervention on youth perception of ease of access to tobacco, and on smoking behaviour.

(Tobacco Control 2000;9:169-176)

Keywords: smoking prevention; sales to minors; young people; systematic review
Controlling access is an established strategy for reducing consumption of substances harmful to health, in particular tobacco, alcohol, and illicit drugs. Of adolescents who try smoking more than a third become daily smokers in secondary school. ${ }^{1}$ Successful restriction of young people's access to tobacco products could help prevent them from developing this addiction. Accordingly, many countries prohibit tobacco sales to minors.

Although young people perceive difficulties in obtaining cigarettes as a deterrent to tobacco use ${ }^{2}$ poor compliance with access laws is well documented. $^{3}$ In most surveys, underage young people report little difficulty when illegally purchasing cigarettes. ${ }^{4-8}$ In the USA a 1998 survey found that $90 \%$ of 10 th grade students (ages 15-16 years) would find it "fairly easy" or "very easy" to get cigarettes. ${ }^{9}$ In a 1997 survey, 30\% of high school smokers reported cigarette purchase in the previous month, of whom less than a third had been asked for proof of age. ${ }^{10}$ In England a 1996 survey suggested that $25 \%$ of all secondary school children had tried to buy cigarettes in a shop in the last year. Only 38\% had been refused at least once. ${ }^{11}$

Furthermore, commercial sources of tobacco are not the only way in which young people obtain products. ${ }^{3}$ They may also get cigarettes from parents, siblings, friends, and by theft. Reducing access to commercial sources could lead to increased use of such sources. In determining policy it is important to know both how best to restrict access, and the likely effect of successful restriction on youth tobacco consumption.

\section{Objective}

The aim of this review was to assess the effectiveness of reducing underage access to tobacco products by deterring shopkeepers from illegal sales. We asked three questions:

(1) Does intervention with retailers, by education, active enforcement of laws, or combinations of strategies lead to decreased sales to minors? Is there evidence that any of the strategies is superior to the others?

(2) Do reduced sales of tobacco to minors lead to a decrease in their self reported ease of access?

(3) Do reduced sales of tobacco to minors reduce prevalence of tobacco use?

\section{Data sources}

We used the Cochrane Tobacco Addiction Group specialised register which has been developed by systematic sensitive searches of

\section{revised form \\ 27 January 2000 . Accepted 14 February 2000 \\ Institute of Health Sciences, Old Road, Headington, \\ lindsay.stead@dphpc.ox.ac.uk 2000 .}


Medline and PsycLit and handsearching of journals, including Tobacco Control. We looked for studies involving restrictions on sales to minors or sales from vending machines, and interventions with retailers related to compliance with legislation. We searched Medline for any other controlled or uncontrolled evaluations. The search strategy is specified in an additional table on the Web site.

\section{Study selection}

TYPES OF STUDIES

We considered studies of measures to improve compliance with laws restricting youth access to retail sales of tobacco, using one of these study designs:

(1) Controlled trials randomising retail outlets, communities or geographical regions.

(2) Controlled trials without randomisation allocating retail outlets, communities or geographical regions.

(3) Time series studies.

(4) Uncontrolled before and after studies.

We excluded uncontrolled studies with post intervention measurements only.

TYPES OF PARTICIPANTS

We evaluated strategies which targeted retailers to reduce tobacco use by minors. Minors were defined by the legal age limit in the communities studied.

TYPES OF INTERVENTION

We considered education, law enforcement, community mobilisation, or combinations of strategies that aimed to deter retailers from selling tobacco to minors.

TYPES OF OUTCOME MEASURES

We considered the outcomes of:

(1) Illegal tobacco sales, assessed by attempted purchase by young people.

(2) Perceived ease of access to cigarettes by young people.

(3) Prevalence of tobacco use among young people. We accepted self reports of tobacco use.

\section{Data extraction}

The review was conducted in four stages:

(1) One reviewer prescreened reports for relevance.

(2) Two reviewers assessed relevant studies independently. To be included they had to meet all the criteria listed above for study design, type of participant and intervention and outcomes assessed.

(3) One reviewer extracted, and the second checked, data from included studies.

(4) Studies were combined using qualitative narrative synthesis.

We chose narrative, rather than quantitative, synthesis because we expected heterogeneity in the study designs, type of interventions and outcomes measured.

\section{Data synthesis}

DESCRIPTION OF INCLUDED STUDIES

A table containing full details of each study including setting, design, intervention and outcomes is available on the Tobacco Control web site.

We identified 27 studies that met the inclusion criteria. Of these, 13 used some form of control group. In six studies the store was the unit of randomisation. ${ }^{12-18}$ One study identified the retailers who made illegal sales to minors at baseline. ${ }^{18}$ These retailers were then randomly allocated to receive a warning letter threatening prosecution, or no letter. One carried out test purchasing around one school and not around another. ${ }^{19}{ }^{20}$ Six studies compared interventions in different communities. Forster and colleagues' tobacco policy options for prevention (TPOP) study randomised 14 Minnesota communities after stratification on baseline variables. ${ }^{21-23}$ Altman and colleagues allocated two pairs of Monterey communities on the basis of a coin toss. ${ }^{24}$ Cummings and colleagues assigned six matched pairs of communities to intervention or control status; within the intervention communities the stores were randomly allocated to different schedules of enforcement checks. ${ }^{13}$ The other three community studies in Massachusetts, ${ }^{25}$ San Diego $^{26} 27$ and Sydney, Australia ${ }^{28}$ compared the intervention communities with a control community in which similar baseline and follow up assessments were conducted, but without random assignment. In Massachusetts, ${ }^{25}$ intervention communities were those in which active enforcement of tobacco sales regulations was intended. The control communities were not planning active enforcement, although by the end of the study some enforcement was being conducted.

The remaining uncontrolled studies compared rates of illegal sales or smoking behaviour before and after an intervention. In some, only the outlets that allowed purchase at baseline were followed up. In Ontario, Canada, a series of interventions were implemented in neighbouring health units and the follow up ranged from two weeks to 21 months. ${ }^{29}$ In Oregon, implementation occurred in eight communities at different time points. ${ }^{30}$

\section{TYPES OF INTERVENTION}

The main interventions were: education about legal requirements; notification of the results of compliance checks; warning of enforcement, and implementation of enforcement by police or health officials. Some studies tested different frequencies of enforcement activity, and different channels of information. In some the intervention included the introduction of new legislation or local ordinances such as a licensing system or a formal requirement for compliance checking.

The TPOP campaign in Minnesota aimed "to make tobacco access by youth a salient community issue, to change local ordinances ... to change retailers' and other adults' practices....and to promote enforcement of tobacco age-of-sale laws". The campaign used a direct action community organising model so 
communities differed in the specific ordinances introduced. These included an increased licence fee for tobacco outlets, penalties for the vendor and the clerk, a requirement for unannounced compliance checks, and bans on vending machines and self service displays. Other studies also included elements to raise community awareness and support. ${ }^{161724}$ 26-28 30-35

In some studies, the intervention had to be modified because of local attitudes. Altman and colleagues were unable to bring about enforcement action because of legal concern about the use of "sting" operations and an unwillingness to prosecute clerks. ${ }^{24}$

In most studies there was dissemination of information to retailers about their legal obligations, including reminders of the age at which purchase was legal, that proof of age should be required before sale, or that warning notices should be displayed. Usually this information was posted, but sometimes mass media channels were used.

OUTCOME ASSESSMENT

Twenty five studies assessed retailer compliance with the law using test purchasers. Most studies focused on "over the counter" sales but some also assessed ease of purchase from vending machines. Some distinguished between sales in shops with behind the counter or locked displays and self service. ${ }^{36}$ One study ${ }^{37}$ investigated vending machine purchases only.

Eight studies assessed the effect of an intervention on the smoking behaviour of underage youth. Five of these were controlled trials. Three assessed retailer behaviour as well, ${ }^{21} 2425$ while one assessed only smoking behaviour. ${ }^{28}$ One assessed smoking prevalence in both areas but retailer behaviour only in the intervention area. ${ }^{19}$ The three uncontrolled studies measured smoking behaviour before and after a change in enforcement practice. Two assessed retailer behaviour as well. ${ }^{32} 3338 \mathrm{Six}$ studies also asked underage smokers where they obtained their cigarettes and how difficult it was to buy them.

EXCLUDED STUDIES

Two surveys have assessed the effect of the tobacco industry sponsored voluntary compliance programme "It's the Law". ${ }^{40}{ }^{41}$ We did not include them because there was no baseline assessment of retailers before they joined the programme. The authors found no evidence that those participating in the scheme were less likely than other retailers to make illegal sales. Reasons for excluding three other studies ${ }^{42-44}$ are given in an additional Web table.

\section{METHODOLOGICAL QUALITY OF INCLUDED}

STUDIES

As we considered a heterogeneity of study designs, we made no attempt at statistical meta-analysis. However, we gave greater weight in our synthesis to the three controlled studies that measured the behaviour of retailers and minors in the community. ${ }^{21}{ }^{24}{ }^{25}$ In uncontrolled studies, background secular change may be incorrectly attributed to an intervention.

Although randomisation by community is a less biased method for assessing the effect of intervention, statistical analysis of such studies should address the issue of clustering of behaviour within communities. Clustering usually increases the required sample size ${ }^{45}$ Few of the included studies directly addressed this issue: another reason why formal meta-analysis could be misleading.

A further methodological concern is the measurement of outcome. In most studies compliance was judged by a single purchase attempt. However, when multiple purchase attempts were made, the estimates of compliance were lower when retailers were classified as non-compliant only if they never sold. Junck and colleagues ${ }^{34}$ found that compliance after intervention was $74 \%$ on the basis of a single purchase attempt at each store, but only $45 \%$ if three attempts were made. This bias may overestimate compliance rates in studies using only one purchase attempt. The age of the assessor also affects measurement of compliance. DiFranza and colleagues showed that 16-17 year olds were more successful than younger children, and girls were more successful than boys. ${ }^{41}$ Sales rates may also be underestimated if test purchasers act differently from true underage purchasers. All the studies which gave details noted that the youths engaged in testing were to state their true age if challenged, and to say that the cigarettes were for their own use.

\section{Results}

DOES INTERVENTION WITH RETAILERS LEAD TO DECREASED SALES TO MINORS?

Eleven controlled trials assessed the effect of an intervention on illegal sales, measured by compliance checks (table 1). Six found that intervention reduced the level of illegal sales compared to the control group. ${ }^{12} 141824-27$

Active enforcement was used in three of the successful interventions. In Chicago, ${ }^{12}$ sales fell marginally in the month after all merchants who had sold cigarettes received a warning, but enforcement produced a much larger fall in sales rates. Media coverage of the study at one point during the follow up period caused a further substantial drop in sales in all groups. This study showed that two monthly enforcement visits were more effective than four and six monthly schedules, giving a sales rate of $19 \%$ in the final six months of the intervention. In Harlem $^{14}$ enforcement produced a substantial decrease in sales, not found after an educational visit alone. However, the rate still fell only to $47 \%$. In Massachusetts, ${ }^{25}$ compliance rates improved from $35 \%$ to $82 \%$ in the intervention communities and from $28 \%$ to $45 \%$ in the control areas.

Three interventions without enforcement produced greater improvements in compliance than in control areas. Project Trust in San Diego $^{26}{ }^{27}$ used multicomponent community and retailer education with personal visits. Sales fell significantly between pre- and postintervention measurement in four out of six 





intervention areas and in no control area. The sales rate was reduced from $70 \%$ to $32 \%$, an effect sustained at six month follow up. In Monterey, ${ }^{24}$ education and community organisation eliminated successful test purchases by the end of a three year project in two communities compared to a $39 \%$ sales rate in the comparison communities. In Sydney ${ }^{18}$ warning letters threatening prosecution to retailers who had made illegal sales led to a second offence rate of $31 \%$, compared to $60 \%$ among those not warned.

Other controlled trials did not find a difference. The comprehensive community approach used in Minnesota reduced successful over the counter purchases in intervention communities from $36.7 \%$ to $3.1 \%$, but the net change was not significantly different from the control communities where the rate fell from $41 \%$ to $8.8 \% .^{21}$ In Santa Clara ${ }^{16}$ there was no additional effect of mailed or personally delivered educational materials without enforcement. However, the community and merchant education media had some short term effect, with sales rates reduced from $74 \%$ to $39 \%$.

In Erie Country there was no effect of education alone ${ }^{46}$ or active enforcement. ${ }^{13}$ In the second study the lack of effect could have been because all stores were sent letters warning of possible random checks. The news of "sting" operations also spread rapidly to the non-enforcement communities. A study in
New South Wales, Australia ${ }^{15}$ used education and the threat of enforcement. Youths old enough to buy cigarettes, but looking younger, were used for compliance checks so the outcome was requiring proof of age before making a sale. There was an overall improvement from $17 \%$ to $43 \%$ in the proportion of retailers requiring such proof, but no difference between intervention and control retailers.

All the uncontrolled studies (table 2) showed reduction in illegal sales following intervention, but the size of the pre- and post-difference was variable, and not always consistent across communities. ${ }^{47}$ There was some evidence that effects declined over time. ${ }^{30}{ }^{38}$ In Oregon, advising retailers whether they had or had not complied with the law at a test purchase had an effect. ${ }^{30}$ In Solana County $^{31}$ a merchant education programme had such a limited effect that a second phase of police enforcement was initiated. This reduced over the counter sales from $74 \%$ to $24 \%$. The highest compliance rates were in Woodridge $(\text { over } 95 \%)^{32}$ and Leominster $(84 \%)^{38}$ which used enforcement, and in Manly $^{34}$ (86\%), Ontario $^{29}(94 \%)$, and Wisconsin ${ }^{48}(82 \%)$ which did not. The lowest was $49 \%$ for baseline noncompliers in Cook County. ${ }^{49}$

In the study of vending machines, a locking device policy resulted in fewer locations selling cigarettes to minors than a policy of no restriction. ${ }^{37}$ However, the authors concluded

Table 2 Results from uncontrolled trials

\begin{tabular}{|c|c|c|}
\hline Studies & Objectives & Outcomes \\
\hline \multirow[t]{2}{*}{$\begin{array}{l}\text { Leominster: DiFranza } e t a l^{38} \\
\text { Education and enforcement }\end{array}$} & Illegal sales & $\begin{array}{l}\text { Sales were refused in } 81 \%, 84 \% \text {, and } 35 \% \text { of tests at each follow up. No baseline assessment of } \\
\text { sales rates and different ages used for test purchasing. }\end{array}$ \\
\hline & Smoking behaviour & Smoking prevalence fell significantly in $12-13$ years and $16-17$ years age groups. \\
\hline \multirow[t]{3}{*}{$\begin{array}{l}\text { Woodridge: Jason } e t a \beta^{323350} \text { Legislation } \\
\text { and enforcement }\end{array}$} & Illegal sales & $\begin{array}{l}\text { Sales were reduced to a minimal level (average }<4 \% \text { in } 5 \text { checks over } 12 \text { months) for the first } 2 \\
\text { years after passage of legislation, as measured by quarterly compliance checks. In later periods } \\
\text { youths were older and sales rates also rose. When a } 17 \text { year old was used } 25 \% \text { sold illegally. }\end{array}$ \\
\hline & Smoking behaviour & $\begin{array}{l}\text { Between } 1989 \text { and } 1991 \text { the proportion of } 7 \text { th- } 8 \text { th graders describing themselves as regular } \\
\text { smokers fell from } 16 \% \text { to } 5 \% \text { and experimenters from } 46 \% \text { to } 23 \% \text {. In } 1996 \text { there were } \\
\text { significantly fewer smokers among a sample of Woodridge students compared to students at the } \\
\text { same school from a non-enforcement community }(42.2 \% v 54.7 \%, \mathrm{p}<0.05) \text {. The difference in } \\
\text { regular smoking was } 8.3 \% v 13.4 \% \text { (NS). }\end{array}$ \\
\hline & Perceived access & $\begin{array}{l}\text { In } 199169 \% \text { of students felt the law would either prevent their procurement of cigarettes or } \\
\text { make them harder to obtain. In } 1996 \text { more Woodridge smokers felt it was difficult or moderately } \\
\text { difficult to get cigs than smokers from non-enforcement community }(20 \% v 14.3 \% \text {, NS). }\end{array}$ \\
\hline \multirow[t]{2}{*}{ Everett: Hinds ${ }^{39}$ Legislation } & Smoking behaviour & $\begin{array}{l}\text { Tobacco use fell from } 25.3 \% \text { to } 19.7 \% \text { (not significant), but reduction among girls was } \\
\text { significant }(26.4 \% \text { to } 11.5 \%) \text {. }\end{array}$ \\
\hline & Perceived access & $\begin{array}{l}\text { Stores as a source of tobacco products did not change significantly, but some reduction was } \\
\text { noted post intervention. Friends increased as a source of tobacco products post ordinance } \\
(p=0.04) \text {. }\end{array}$ \\
\hline $\begin{array}{l}\text { Alberta (Compliance for Kids): } \\
\text { Abernathy }{ }^{47} \text { Legislation and } \\
\text { education }\end{array}$ & Illegal sales & $\begin{array}{l}\text { There was some reduction in willingness to sell in all three communities. The change was } \\
\text { significant only in controls: pre } 57.1 \% \text {, post } 14.3 \%(\mathrm{p}<0.02) \text {. }\end{array}$ \\
\hline $\begin{array}{l}\text { Bristol: Naidoo and Platts }{ }^{54} \\
\text { Education and publicity }\end{array}$ & Illegal sales & $\begin{array}{l}91 \%(\mathrm{n}=100) \text { sold at baseline, } 44 \%(\mathrm{n}=50) \text { sold at } 1 \text { year. New guidelines and publicity } \\
\text { materials were issued nationally between baseline and follow up. }\end{array}$ \\
\hline $\begin{array}{l}\text { Cook County: McDermott et al } \\
\text { Education and warning }\end{array}$ & Illegal sales & $120 / 129$ non-compliant stores revisited. Purchase success rate fell to $51 \%$. \\
\hline $\begin{array}{l}\text { Manly: Junck et a } \beta^{4} \text { Community }+ \\
\text { feedback }\end{array}$ & Illegal sales & $\begin{array}{l}\text { Purchase success fell. At baseline } 52 \% \text { of outlets sold ( } 85 \% \text { if up to } 3 \text { attempts), fell to } 26 \% \text { ( } 55 \% \\
\text { if } 3 \text { attempts) at } 3 \text { months, and } 14 \% \text { at } 10 \text { months. }\end{array}$ \\
\hline Ontario: Dovell et a ${ }^{29}$ Education & Illegal sales & $\begin{array}{l}\text { In KFL\&A willingness to sell fell from } 46 \% \text { at baseline to } 43 \% \text { after general education and to } 6 \% \\
\text { after receiving kit. Also effect in H\&PE, } 47 \% \text { to } 2 \%, 1 \text { week after intervention. }\end{array}$ \\
\hline $\begin{array}{l}\text { Oregon (Project SixTeen): Biglan et } \\
\mathrm{al}^{30}{ }^{55} \text { Community }+ \text { feedback }\end{array}$ & Illegal sales & $\begin{array}{l}\text { There was a significant reduction in the mean level of sales, from } 57 \% \text { to } 22 \% \text {, based on multiple } \\
\text { assessments in } 8 \text { communities. }\end{array}$ \\
\hline $\begin{array}{l}\text { Perth: Mawkes et al }{ }^{35} \text { Community }+ \\
\text { enforcement }\end{array}$ & Illegal sales & $\begin{array}{l}\text { At baseline } 89 \% \text { of outlets prepared to sell. At follow up overall rate fell to } 28 \% \text {, but substantial } \\
\text { variation by area. }\end{array}$ \\
\hline $\begin{array}{l}\text { Solana County: Feighery et al } l^{11} \\
\text { Retailer education }+ \text { enforcement }\end{array}$ & Illegal sales & $\begin{array}{l}73 \% \text { sold at pretest, } 68 \% \text { at post-test } 1 \text { (after education), } 31 \% \text { at post-test } 2 \text { (after enforcement). } \\
\text { Change in over counter sales significant. Vending machine sales remained high. }\end{array}$ \\
\hline $\begin{array}{l}\text { St Paul: Forster et } a l^{37} \text { Vending } \\
\text { machine locks }\end{array}$ & Illegal sales & $\begin{array}{l}1 \text { year after the law } 47 \% \text { with locks, } 30 \% \text { were still not in compliance. Overall purchase success } \\
\text { rate was } 86 \% \text { before law, } 30 \% \text { at } 3 \text { months and } 48 \% \text { at } 1 \text { year. }\end{array}$ \\
\hline Stirling: Campbell ${ }^{56}$ Warning & Illegal sales & $\begin{array}{l}\text { At baseline } 37 \% \text { sold. Of } 13 \text { revisited, only } 1 \text { sold at follow up. Among outlets visited for first } \\
\text { time at follow up survey, sales rate } 35 \% \text {. }\end{array}$ \\
\hline $\begin{array}{l}\text { Wisconsin: Schensky et } a l^{48} \text { Education } \\
\text { and feedback }\end{array}$ & Illegal sales & $\begin{array}{l}40 \% \text { permitted purchase at baseline and } 18 \% \text { at follow up. Of those who permitted purchase at } \\
\text { baseline } 25 \% \text { permitted at follow up. }\end{array}$ \\
\hline
\end{tabular}

KFL\&A, Kingston Frontenac Lennox and Addington Health Unit; H\&PE, Hastings and Prince Edward Counties Health Unit. 
that it was probably less effective than the major policy alternative, a ban on vending machines.

DO REDUCED SALES OF TOBACCO TO MINORS LEAD TO A REDUCTION IN MINORS' SELF REPORTED EASE OF ACCESS?

Six studies assessed perceived ease of access. In three, intervention was associated with decreased test sales. In Monterey ${ }^{24}$ self reported recent purchase of tobacco was less frequent among seventh grade students (ages 12-13) in the intervention than in the control communities. In the other two grades there were large baseline differences in the proportion reporting a purchase in the last three months, so longitudinal changes were difficult to interpret. However, at the final follow up recent purchase was significantly less common among intervention community ninth grade students (ages 14-15). After intervention in Woodridge, ${ }^{32} 69 \%$ of students said that the law would make cigarettes harder to obtain. In 1996 more Woodridge smokers felt it was difficult or moderately difficult to get cigarettes than smokers from another community $\left(20 v 14.3 \%\right.$, not significant). ${ }^{32}$ In Massachusetts $^{25}$ despite an effect of intervention on sales there was no difference in perceived ease of access. There were significant falls in the proportion who had tried to buy tobacco in the previous six months, and increases in those who were refused at least half the time. Since these occurred in all communities they could not be attributed to the active enforcement programme. There were also similar changes across intervention and control communities in reported source of cigarettes. Fewer youths bought tobacco in their own city or town and more bought it elsewhere or had someone buy it for them.

In Minnesota, ${ }^{21}$ the proportion who perceived high availability decreased in the intervention communities while increasing in the control communities, despite similar levels of retailer compliance. The proportion of adolescents reporting at least one purchase attempt in the previous month declined in the intervention communities while it increased in the control communities. The authors suggested that these changes might be attributable to the community awareness and mobilisation campaigns that were a part of the intervention.

In Sydney ${ }^{28}$ there was a significant reduction in the proportion of male students who rated purchasing cigarettes from petrol stations as "easy" or "very easy" postintervention, but no other significant changes for the six categories of purchase source. In Everett ${ }^{39}$ more students reported that retailers asked for proof of age. Neither of these studies directly assessed retailer behaviour. In Gateshead few children reported being refused, with no change over time. ${ }^{1920}$

DO REDUCED SALES OF TOBACCO TO MINORS DECREASE PREVALENCE OF TOBACCO USE? Three of five controlled trials found an effect of intervention on youth smoking behaviour. Alt- man and colleagues ${ }^{24}$ found a lower smoking prevalence in those who were in seventh grade at baseline, but the effect was not sustained at the end of the 32 month study. There were no significant differences among the other age groups.

In Minnesota, there was a lower rate of increase in all measures of smoking prevalence in seven areas with a comprehensive community based intervention than in seven control communities. The net difference in prevalence was significant for daily, but not weekly or monthly, smoking. ${ }^{21}$ They concluded that refusals by sellers at the time of purchase attempts by young people did not account for the lower adolescent smoking rates seen in the intervention communities, since all communities showed increases in compliance. Other components of the intervention may have changed young people's behaviour. Businesses in the intervention communities were more likely to post warning notices and to store cigarettes behind the counter.

Staff and colleagues assessed a community intervention in Sydney with education of retailers and local publicity, measuring smoking behaviour and reported ease of purchase but not illegal sales. ${ }^{28}$ There was an effect of intervention only in the youngest students.

Two studies did not find evidence of change in smoking behaviour. In Massachusetts ${ }^{25}$ there was no difference in the rate of change of prevalence of "any tobacco use" or "daily tobacco use" between the intervention and control communities. The rate of "current tobacco use" rose marginally in the intervention communities but remained stable in controls, with borderline significance for the comparison between group trends. In Gateshead, an intervention of test purchases in the intervention area resulted in full compliance and hence no prosecutions, although children in the area reported buying cigarettes with ease. There was no change in smoking prevalence. ${ }^{19}$

In the light of these findings, three uncontrolled studies should be interpreted with caution. Two reported a decrease in smoking prevalence in students associated with a reduction in illegal sales in single intervention communities. $^{32} 33383950$ In Woodridge the proportion of regular smokers among seventh and eighth grade students (ages 12-14 years) fell from $16 \%$ to $5 \%$. In this study ${ }^{32}$ access was very successfully restricted, and possession of tobacco by a minor was also an offence. Longer term assessments in this community using older youths showed higher rates of sales, although still below 20\%. ${ }^{33}$ A survey in 1996 found a lower proportion of smokers among Woodridge students than students from a community not conducting regular enforcement. ${ }^{50}$ In Leominster there was a fall in smoking prevalence in three out of four age groups. ${ }^{38}$ In Everett ${ }^{39}$ there was no significant change in overall reported tobacco use after introduction of a local ordinance, but there was a significant decrease among girls. 


\section{Conclusions}

This review provides evidence about the relative effectiveness of different interventions for reducing tobacco sales by retailers. Simply giving information to retailers about the law is not effective. DiFranza and colleagues showed that merchant participation in voluntary compliance programmes was low. ${ }^{40}$ There is evidence that interventions to educate retailers can improve compliance, but the successful interventions used a variety of strategies, including personal visits and mobilising community support. ${ }^{24}$

Enforcement, or warnings of it, generally had an effect on retailer behaviour. Sustaining compliance requires regular enforcement, and the existing evidence suggests reduced effectiveness if checking occurs much less than 4-6 times a year. ${ }^{12}$ The penalty for infringement may also be important, although there is little direct evidence of the relative deterrent effect of different penalties. If fines for offenders are low, retailers may become inured to the threat of a prosecution, diminishing the effect of warnings or prosecutions. Removal of a license to sell tobacco could be more effective, if the licensing itself is strictly monitored. ${ }^{18}$ Imposing too harsh a penalty may, however, be counterproductive if community attitudes are not supportive. In one study using enforcement, judges were inclined to give suspended sentences because they felt that imposing a heavy fine or criminal record on the clerks making the sale was inappropriate. ${ }^{31}$ Enforcement may produce a backlash against tobacco control activities if the value of reducing sales has not been adequately publicised. A graduated system of penalties from a warning to a fine and then loss of licence may be most appropriate where legal systems allow it. The combination of enforcement and fines on youth users was associated with high compliance rates in Woodridge, but punishing the user may not gain widespread acceptance. ${ }^{51}$

Retailer interventions may not work if neighbouring districts have discordant policies. Retailers who make illegal sales argue that minors will simply go elsewhere, depriving them of revenue without benefiting the community. ${ }^{52}$ Uniform enforcement policies may help retailers to comply by reassuring them that their competitors will do the same. Similarly, fitting locks to vending machines is probably less effective than banning them. ${ }^{37}$

The main methodological problem in evaluating retailer interventions is that assessment of retailer behaviour during compliance checks does not show whether smoking behaviour by minors has changed, or even how easy it is for them to buy tobacco. Retailers may be able to identify "test" purchasers, especially if they know or suspect that checks are being made. "Real" purchasers may be known to the sales clerks, may lie about their age or may behave differently. If retailers are aware of the possibility of compliance checks they may sell only to young people they know. Young people may also change their source, by going to another community or by asking someone else to make the purchase for them. ${ }^{25}$ Measuring changes in self reported ease of access to tobacco is important to show that an intervention has had an impact on purchasing behaviour. If minors do not perceive that buying tobacco has become more difficult, then it is unlikely that they have changed their use of tobacco. Conversely, a change in smoking behaviour can most confidently be attributed to a change in retailer behaviour if the intermediate outcome of a change in perception of ease of access has also been observed. This is an important message for future research in this area.

There are a number of problems in drawing conclusions about the effectiveness of interventions with retailers for reducing youth tobacco use. In particular, effectiveness can only be assessed if tobacco sales are reduced. If some retailers continue to sell, a channel of access will exist. Many of the communities studied achieved large decreases in sales, but none achieved complete, sustained compliance. Hence it is not surprising that there is only limited evidence from controlled trials that reducing the ease with which underage youth can purchase cigarettes will reduce their use of tobacco. Some uncontrolled studies, notably Woodridge, have reported impressive reductions in youth smoking behaviour in association with interventions achieving high compliance. This might suggest that there is a threshold level of compliance above which access can be effectively reduced. This hypothesis needs testing prospectively. The findings from Massachusetts ${ }^{25}$ suggest that, if there is such a threshold, it must be greater than $80 \%$; density of vendors may be another determinant of availability. The challenge for future research on the effects of restriction of underage sales is to ensure effective implementation of the intervention. Translating access restriction from research to practice is a further challenge. In the USA, despite federal legislation in 1992 (the Synar Amendment) requiring all states to enact and enforce a law to prohibit sale of tobacco to minors, surveys have shown no change from 1992 to 1997 in the proportion (almost 90\%) of 10th grade students who believed that they can easily obtain tobacco products. ${ }^{53}$

A further limitation of current research is that it is largely confined to more developed countries. The effectiveness and feasibility of retailer interventions will depend on the attitudes and available resources in different societies. With the acceleration of tobacco use in the developing world there is a particular need for cost effective interventions to prevent uptake of smoking by the youth of these societies.

A version of this review has been published in the Cochrane Library. Cochrane systematic reviews are regularly updated to include new research, and in response to comments and criticisms from readers. If you wish to comment on this, or other Cochrane reviews of interventions for tobacco control, please send it to lindsay.stead@dphpc.ox.ac.uk. Information about the Cochrolndsay.stead@dphc.ox.ac.uk. Information about the Library is available from www.cochrane to the Cochrane Library is available from www.cochrane.org. We wish to acknowledge the support for the Cochrane Tobacco Addiction Group from the UK NHS Research and Development the editors of Tobacco Control for agreeing to publish this the editors
version. 
1 US Centers for Disease Control and Prevention. Selected cigarette smoking initiation and quitting behaviors among bid Mortal Wkly Rep 1998;47:386-9.

2 Stanton WR, Mahalski PA, McGee R, Silva PA. Reasons for smoking or not smoking in early adolescence. Addict Behav

3 Forster JL, Wolfson M. Youth access to tobacco: policies and politics. Annu Rev Public Health 1998;19:203-35.

4 Carruthers S, McDonald C. The availability of cigarettes to minors in Perth, Western Australia. Tobacco Control 1995;4:49-52.

5 Erickson AD, Woodruff SI, Wildey M, Kenney EM. Baseline assessment of cigarette sales to minors in San Diego, California. 7 Comm Health 1993;18:213-14.

6 Forster JL, Hourigan M, McGovern P. Availability of cigarettes to underage youth in three communities. Prev Med 1992;21:320-8.

7 Sanson Fisher RW, Schofield MJ, See M. Availability of cigarettes to minors. Aust f Public Health 1992;16:354-9.

8 US Centers for Disease Control and Prevention. Youth risk behavior surveillance-United States, 1995. MMWR CDC Surv Summ 1996;45(SS-4): 1-84.

9 Johnston LD, O'Malley PM, Bachman JG. National survey results on drug use from the Monitoring the Future study, 1975-1998 Volume I: Secondary school students. Rockville, MD: National Institute on Drug Abuse, 1999. (NIH Publication No. 99-4660))

10 US Centers for Disease Control and Prevention. Youth risk behavior surveillance-United States, 1997. MMWR CDC Surv Summ 1998;47(SS-3): 1-90.

11 Jarvis, L. Smoking among secondary school children in 1996: England. An enquiry carried out by the Social Survey Division of ONS on behalf of the Department of Health. London: HMSO, 1997. http://www.doh.gov.uk/pub/docs/doh/ survey6.pdf

12 Jason L, Billows W, Schnopp Wyatt D, King C. Reducing the illegal sales of cigarettes to minors: analysis of alterna-
tive enforcement schedules. F Appl Behav Anal 1996; tive enfor

13 Cummings KM, Hyland A, Saunders-Martin T, et al. Evaluation of an enforcement program to reduce tobacco
sales to minors. Am 7 Public Health 1998;88:932-6. $\mathrm{S}$, Healton E. Laying down the law: reducing illega tobacco sales to minors in central Harlem. Am f Public Health 1998;88:936-9.

15 Schofield MJ, Sanson Fisher RW, Gulliver S. Interventions with retailers to reduce cigarette sales to minors: randomised controlled trial. Aust $N Z 7$ Public Health 1997;21:590-6.

16 Altman DG, Rasenick-Douss L, Foster V, Tye JB. Sustained effects of an educational program to reduce sales of

17 Altman DG, Foster V, Rasenick-Douss L, Tye JB. Reducing the illegal sale of cigarettes to minors. $\mathscr{f} A M A 1989 ;$ 261:80-3.

18 Chapman S, King M, Andrews B, McKay E, Markham P, Woodward S. Effects of publicity and a warning letter on
illegal cigarette sales to minors. Aust 7 Public Health 1994; 18:39-42

19 Bagott M, Jordan C, Wright C, Jarvis S. Test sales do not have impact on prevalence of smoking by children. $B M \mathcal{F}$ 1997;315:491

20 Bagott M, Jordan C, Wright C, Jarvis S. How easy is it for young people to obtain cigarettes, and do test sales by trading standards have any effect? A survey of two schools in Gateshead. Child Care Health Dev 1998;24:207-16.

21 Forster JL, Murray DM, Wolfson M, Blaine TM, Wagenaar AC, Hennrikus DJ. The effects of community policies to reduce youth access to tobacco. Am 7 Public Health 1998 88:1193-8.

22 Forster JL, Wolfson M, Murray DM, Wagenaar AC, Claxton AJ. Perceived and measured availability of tobacco to youths in 14 Minnesota communities: the TPOP study. Am f Prev Med 1997;13:167-74.

23 Blaine TM, Forster JL, Hennrikus D, O'Neil S, Wolfson M, Pham H. Creating tobacco control policy at the local level: implementation of a direct action organizing approach. implementation of a direct action
Health Educ Behav 1997;24:640-51.

24 Altman DG, Wheelis AY, McFarlane M, Lee H, Fortmann SP. The relationship between tobacco access and use among adolescents: a four community study. Soc Sci Med 1999;48:759-75.

25 Rigotti NA, DiFranza JR, Chang Y, Tisdale T, Kemp B, Singer DE. The effect of enforcing tobacco-sales laws on adolescents' access to tobacco and smoking behavior. N Engl F Med 1997;337:1044-51

website extra

Additional tables appear on the Tobacco Control website

www.tobaccocontrol.com

26 Keay KD, Woodruff SI, Wildey MB, Kenney EM. Effect of a retailer intervention on cigarette sales to minors in San Diego County, California. Tobacco Control 1993:2:145-51.

27 Wildey MB, Woodruff SI, Agro A, Keay KD, Kenney EM, Conway TL. Sustained effects of educating retailers to reduce cigarette sales to minors. Public Health Rep 1995;110:625-9. 1993;18:321-9.

14 Gemson DH, Moats HL, Watkins BX, Ganz ML, Robinson

28 Staff M, March L, Brnabic A, et al. Can non-prosecutory enforcement of public health legislation reduce smoking among high school students? Aust $N Z$ I Public Health $1998 ; 22: 332-5$.

29 Dovell RA, Mowat DL, Dorland J, Lam M. Changes among retailers selling cigarettes to minors. Can $\mathcal{F}$ Public Health 1996;87:66-8.

30 Biglan A, Ary D, Koehn V, et al. Mobilizing positive reinforcement in communities to reduce youth access to tobacco. Am f Community Psychol 1996;24:625-38.

31 Feighery E, Altman D, Shaffer G. The effects of combining education and enforcement to reduce tobacco sales to minors. A study of four northern communities. $\mathcal{F} A M A$ 1991;266:3168-71.

32 Jason LA, Ji PY, Anes MD, Birkhead SH. Active enforcement of cigarette control laws in the prevention of cigarette sales to minors. $¥ A M A$ 1991;266:3159-61.

33 Jason LA, Billows WD, Schnopp-Wyatt D, King C. Long-term findings from Woodridge in reducing illegal cigarette sales to older minors. Evaluation and the Health Professions 1996;19:3-13.

34 Junck E, Humphries J, Rissel C. Reducing tobacco sales to minors in Manly: 10 months follow-up. Health Promot 7 Aust 1997; 7:29-34.

35 Mawkes L, Wood L, Markham P, Walker N, Swanson M, De Klerk N. Choking the supply: restricting the sale of cigarettes to children in Western Australia. Health Promot $\mathcal{f}$ Aust 1997;7:22-8.

36 Wildey MB, Woodruff SI, Pampalone SZ, Conway TL Self-service sale of tobacco: how it contributes to youth access. Tobacco Control 1995;4:355-61.

37 Forster JL, Hourigan ME, Kelder S. Locking devices on cigarette vending machines: evaluation of a city ordinance. Am f Public Health 1992;82:1217-21.

38 DiFranza JR, Carlson RP, Caisse RE. Reducing youth access to tobacco. Tobacco Control 1992;1:58

39 Hinds MW. Impact of local ordinance banning tobacco sales to minors. Public Health Rep 1992;107:355-8.

40 DiFranza JR, Brown LJ. The Tobacco Institute's "It's the Law" campaign: has it halted illegal sales of tobacco to children? Am 7 Public Health 1992;82:1271-3.

41 DiFranza JR, Savageau JA, Aisquith BF. Youth access to tobacco: the effects of age, gender, vending machine locks, and "It's the law" programs. Am f Public Health 1996;86:221-4

42 Cummings $\mathrm{KM}$, Coogan $\mathrm{K}$. Organizing communities to prevent the sale of tobacco products to minors. Community Health Education 1992;13:77-86.

43 Lewis RK, Paine Andrews A, Fawcett SB, et al. Evaluating the effects of a community coalition's efforts to reduce illegal sales of alcohol and tobacco products to minors. 7 Community Health 1996;21:429-36.

44 Woodruff SI, Wildey MB, Conway TL, Clapp EJ. Effect of a brief retailer intervention to reduce the sale of single ciga-
rettes. American fournal of Health Promotion 1995;9:172-4.

45 Altman DG, Bland JM. Statistics notes. Units of analysis. BM7 1997;314:1874.

46 Skretny MT, Cummings KM, Sciandra E, Marshall J. An intervention to reduce the sale of cigarettes to minors in New York State. N Y State f Med 1990;92:521-5.

47 Abernathy TJ. Compliance for kids: a community-based tobacco prevention project. Can f Public Health 1994; 85:82-4.

48 Schensky AE, Smith SS, Icenogle DL, Fiore MC. Youth tobacco sale compliance checks: impact on vendor practices and community policy. Wis Med 7 1996;95: $775-8$.

$49 \mathrm{McDermott}$ SR, Scott KL, Frintner MP. Accessibility of cigarettes to minors in suburban Cook County, Illinois. $\mathcal{F}$ Community Health 1998;23:153-60.

50 Jason LA, Berk M, Schnopp WD, Talbot B. Effects of enforcement of youth access laws on smoking prevalence. Am f Community Psychol 1999;27:143-60.

51 Mosher JF. The merchants, not the customers: resisting the alcohol and tobacco industries' strategy to blame young people for illegal alcohol and tobacco sales. F.Public Health Policy 1995;16:412-32.

52 Landrine H, Klonoff EA, Fritz JM. Preventing cigarette sales to minors: the need for contextual, sociocultural analysis. Prev Med 1994;23:322-7.

53 DiFranza JR. Are the federal and state governments complying with the Synar Amendment. Arch Pediatr Adolesc Med 1999;153:1089-97.

54 Naidoo J, Platts C. Smoking prevention in Bristol, getting the maximum results using the minimum resources. Health Educ $\mathcal{F} 1985 ; 44: 39-42$
55 Biglan A, Henderson J, Humphrey D, et al. Mobilising positive reinforcement to reduce youth access to tobacco. Tobacco Control 1995;4:42-8.

56 Campbell, F. Youth access to tobacco: an investigation into the sale of cigarettes to young people under the age of 16 years, in the Stirling area. Forth Valley Health Board Health Promotion Department, November 1997. 